\title{
Lagged Learning and the Response to Equilibrium Shock: The Global Financial Crisis and IMF Surveillance
}

\author{
MANUELA MOSGHELLA Sociology, University of Trento
}

\begin{abstract}
The paper investigates the changes to the Fund's bilateral surveillance policy in the wake of the global financial crisis of $2007^{-0}$ - asking about the factors that caused the quick and deep shift to a systemic surveillance approach. In answering this question, the paper argues that the causes of the quick and deep transformation of IMF surveillance lie in the preceding two decades of incremental accumulation of knowledge and small transformations in policy instruments and organizational practices. In identifying the causes of present policy choices in the lessons drawn from past experience, the paper provides an example of lagged learning because the lessons drawn from the ig9os emerging market crises exerted their full impact only as a response to the global financial crisis. These findings therefore contribute to the literature that aims at showing the importance of temporality and process sequencing to explain policy change.
\end{abstract}

Key words: IMF, surveillance, crisis, learning, sequencing

\section{Introduction}

Among the variety of reform proposals triggered by the global financial crisis of $2007^{-09}$, one of the most advocated reforms is the adoption of a systemic approach to financial supervision, according to which supervisory authorities should take into account the safety and soundness of the international financial system as a whole along with that of individual institutions and countries. In other words, while in the run-up to the crisis, the dominant approach to financial supervision was largely based on ensuring the safety and soundness of individual financial institutions in a single country, by relying on the principles of market discipline and selfregulation, ${ }^{\mathrm{I}}$ in the aftermath of the crisis, policy-makers and regulators are converging on a more holistic vision of risk as the primary guiding principle of financial supervision. Although the debate on macroprudential supervision is still in its infancy, the new approach differs from its predecessor because it implies a higher degree of authorities' intervention and counter-cyclical 
policies (for instance, IMF, Bank for International Settlements, and the Financial Stability Board 2009).

Nowhere is this shift more evident than in workings of the International Monetary Fund (IMF). Indeed, the Fund was created in 1944 to preside over the stability of the international financial system. The Fund primarily discharges this mandate by analyzing each member's economic policies and giving advice to the national authorities on how to change them, through the so-called Article IV surveillance reports. One of the characteristics of the Fund's bilateral surveillance is its predominant one-country focus. That is to say, IMF surveillance is meant to detect the problems in domestic policies that risk undermining the member's own domestic stability. Nevertheless, in the aftermath of the 2007-09 financial crisis, IMF surveillance has started taking on an explicit multilateral or systemic focus. Specifically, IMF surveillance has been reformed in order to give the Fund the task of assessing whether domestic policies have negative implications not only for the member's own stability but also for international financial stability.

The transformation of IMF surveillance as a response to the financial crisis is puzzling under several respects. To start with, the shift to a systemic oversight approach in IMF surveillance is a profound transformation of the Fund's activity as compared to the slow-moving development of IMF surveillance over the decades. ${ }^{2}$ For instance, the historical development of IMF surveillance has been so gradual that the IMF Managing Director has recently acknowledged that, in the run-up to the global financial crisis, 'surveillance [had] lagged behind global economic and financial developments' (Strauss-Kahn 2010). The change to IMF surveillance is also all the more puzzling because it began and picked up momentum at a moment when other major reforms to IMF's policies were stalling - including the reform of the Fund's governance which is expected to increase the representation of developing and emerging market countries. Finally, the quick shift to a systemic oversight approach is also puzzling as compared to the traditional practice of bilateral surveillance. In particular, shifting to a systemic surveillance approach requests a demanding organizational effort from the Fund - i.e. it requires the Fund to develop resources to collect and pool information on a wide range of potential sources of financial risks. A systemic approach to financial surveillance also requires the Fund to develop and operationalize new standards against which to assess domestic policies. Interestingly, however, in spite of the difficulties associated with the shift towards systemic surveillance, the IMF has quickly changed its policy as a response to the latest global financial crisis.

This paper examines and explains this empirical pattern of quick and abrupt change. In doing so, it contends that the IMF policy shift cannot be fully grasped by relying on the punctuated equilibrium model of change that is frequently embedded in conceptualizations of policy change. 
That is to say, the policy change under examination cannot be theorized as a dramatic reconfiguration, arising from a large-scale shift in exogenous conditions. Rather, the paper argues and illustrates that the transformation in the Fund surveillance policy can be explained only with reference to the preceding two decades of incremental accumulation of knowledge and small transformations in policy instruments and organizational practices. Specifically, the lessons drawn from the 1994 Mexican crisis and the $1997-8$ Asian crisis led to a number of small and incremental changes to IMF surveillance that structured the options available for the next round of reform in the aftermath of the financial crisis of 2007-09.

Emphasizing the importance of past lessons to present policy choices, the paper therefore provides a case-study of lagged learning - i.e. a case where the lessons drawn from experience are not entirely transmitted to the policy outcomes but are delayed. In the case study under investigation here, factors related to both the supply and the demand side of the policy-making slowed down the effects of learning that followed the Mexican and the Asian crises. On the supply side, the expertise and organizational structure of policy entrepreneurs - i.e. IMF staff members - prevented the Fund from developing fully-fledged understandings of the relationship between financial sector weaknesses and global macroeconomic and financial stability. ${ }^{3}$ For instance, the dominant macroeconomic expertise of IMF staff helps explain why, in spite of the alarm bell sounded by the crises of the I99os, staff continued to focus on factors such as global imbalances and disorderly dollar decline as the key risks to global stability, largely failing to take action to address the risks building up in the financial sector. Furthermore, the hierarchical organization of IMF staff members created the conditions for marginalizing the views of those experts that were advocating more radical innovation of financial surveillance, by moving beyond the micro principles of market discipline and self-regulation (IEO 2011: Annex 4). On the demand side, the effects of learning were delayed because of the complex staff-members relationship. The relationship with the Fund's most powerful member countries is particularly important here. Indeed, as is now widely documented (IEO 20II: 2I), IMF staff members were 'overly influenced by (and sometimes in the awe of) the [advanced countries] authorities' reputation and expertise' therefore feeling uncomfortable challenging their views on financial regulatory and supervisory issues. As a result, the Fund embraced the principles that informed supervisory frameworks such as those of the United States and the UK where light-touch, microprudential supervision held sway.

Although the effects of learning were delayed, it does not mean that they were completely eliminated. Rather, the lessons of the Ig9os led to a number of small, but highly consequential, policy changes. Three gradual changes are particularly important to the present institutional trajectory of 
IMF surveillance. First, the experience of the Mexican and the Asian crisis contributed to the expansion of IMF knowledge on macro-financial linkages and on financial sector issues at large. Second, based on the experience of the I990s crises, the Fund added new policy instruments to its policy toolkit to monitor member countries' financial policies and the global financial system. Finally, by the end of the I9gos, the IMF had converted its organizational resources - including its staff and departments to the task of financial sector surveillance. In short, the changes adopted in the wake of the Mexican and the Asian crises followed the incremental pattern of layering and conversion (Streeck and Thelen 2005; Thelen 2004). These incremental changes provided the building blocks for the Fund's response to the financial crisis of 2007-09. In particular, IMF staff members drew on the knowledge and the policy instruments developed within the Fund over the past decades to advance their agenda on the reform of IMF surveillance. Specifically, they justified their proposal to make the Fund a systemic supervisor in light of past reforms, which had given the Fund the theoretical and organizational resources to carry out the new type of surveillance.

Before proceeding, two clarifications are in order. Firstly, the switch to a systemic oversight approach to financial surveillance is one of the most important developments in response to the latest financial crisis. It has not just occurred in relation to IMF surveillance but also in the movement towards macro-prudential regulation in international supervisory bodies such as the Bank for International Settlements and the Financial Stability Board (see, for instance, Baker 2010). Indeed, one of the lessons drawn from the crisis has been that micro assessments of risk and financial stability based on analysis of individual component parts of a financial system are inadequate, but need to be accompanied by analyses of the aggregate impact of the interaction between individual component parts. Comparing these views with the ones that prevailed in regulatory circles in the run-up to the crisis, the shift towards a systemic approach represents a profound transformation in the principles governing the financial system. Indeed, the long-standing approach has been that of a 'hands-off supervisory style, where the belief that the private sector "knows best" was permitted to take hold' (Kodres and Narain 20I0: 4). In other words, there was a strong presumption that market actors could look after themselves and contribute to international financial stability: market discipline was widely regarded as a stabilizing force (Helleiner, Pagliari and Zimmermann 2009). The systemic approach sponsored in the aftermath of the crisis, in contrast, is staked on the premise that markets require strong regulatory and supervisory mechanisms to function effectively, thereby opening the door to public intervention. Given the important differences in the principles governing the approach to financial surveillance before and after the 
2007-09 crisis, it would be interesting to assess whether such a shift can be interpreted as a paradigmatic or third-order change (Hall 1993). Nevertheless, this paper takes a more limited perspective by focusing solely on the shift that has occurred within the IMF. That is to say, the paper does not investigate the process that led to the emergence of a new systemic approach to financial surveillance at the global level but solely focuses on the process through which the new approach has been endorsed in the Fund's surveillance.

Secondly, some clarification is needed with regard to the type of policy analysed in this paper, that is to say, the policy of an international organization (IO) such as the IMF. Indeed, scholarship on policy studies has somehow neglected the policies of IOs as a research object. Rather, within the field of political science, scholars of international relations (IR) and international political economy (IPE) have traditionally developed the study of IOs (Barnett and Finnemore 2004; Martin and Simmons 1998). This paper nonetheless builds on the assumption that the activities of the IMF, like those of most international organizations, can well be conceived of as public policies. Indeed, similarly to what domestic policies do, IMF policies are meant to respond to societal problems and promote public debate around an issue (Newton and van Deth 2005: 263). Furthermore, in terms of the process through which they are adopted, IMF policies go through the common policy-cycle, ranging from the stage of agenda-setting to the one of decision and implementation during which a variety of institutional procedures and actors are at play. In particular, the IMF's policy-making process is characterized by the interaction of member countries' representatives sitting in the IMF Executive Board, which is the main policymaking body, and IMF staff members, who prepare the policy proposals and have the responsibility to implement policy decisions. ${ }^{4}$

Studying IMF policies differs significantly from studying domestic policy-making. In considering and drafting policies, IMF state representatives and IMF staff do not face the issue of re-election. Nevertheless, the IMF still confronts an issue of legitimacy conceived of as support that makes it accountable to its stakeholders (Seabrooke 2007). Furthermore, studying IMF policies also requires taking into consideration the interaction among the multiple levels where policy is debated and adopted, including the domestic and the supranational level. In light of the internationalization and Europeanization pressures that often influence domestic policy, however, studying the interaction among multiple levels is not a novelty for the literature of policy studies. Hence, the key point here is that it is possible to analyse IMF surveillance in a similar manner as most domestic and EU policies are studied. That is to say, the concepts and tools that are commonly applied to the study of public policies can well be applied to the study of the workings of the IMF. 
The paper develops the argument in three steps. First, the paper reviews alternative explanations for the quick and profound change in IMF surveillance and clarifies the theoretical argument that will be tested in the empirical analysis. Second, the paper describes the key features of the Fund's bilateral surveillance and the main reforms introduced in the aftermath of the latest financial crisis. Finally, drawing from IMF archival documents and internal reviews, the paper shows how the process of learning in the aftermath of the Mexican and the Asian crisis and its lagged effects created the necessary preconditions to the shift to a systemic approach in IMF surveillance. The last section concludes by reflecting on the empirical findings.

\section{The Implications of Lagged Learning}

As has been noted, studies on policy change have advanced to the point where there is a sort of agreement upon a general basic pattern of policy dynamics (Howlett 2009). This pattern reproduces homeostatic models in which exogenous shocks undermine institutionally-entrenched policy equilibria determining a punctuated equilibrium dynamics (Cashore and Howlett 2007).

Baumgartner and Jones (1993) set forth the punctuated equilibrium thesis to explain both policy stability and rapid and radical policy change. Two assumptions guided their analysis. The first is that governments cannot attend all issues simultaneously, hence, governmental priorities change over time. The second is that existing institutions and, in particular, existing policy subsystems prevent and constrain policy change. In other words, institutional frictions characterize policy-making. Under these conditions, political systems drift incrementally most of the time only to be roused to major action when collective attention is galvanized around an issue. That is to say, dramatic policy shifts are generally associated with heightened governmental attention around an issue or increased attention within a policy-making venue that had previously not been involved. 'As pressure for change builds up, it may be resisted successfully for a time. But if pressures are sufficient, they may lead to a massive intervention by previously uninvolved political actors and governmental institutions' (True et al. I999: гог).

At first sight, this perspective appeals as it seems to capture the policy dynamics of the case under investigation. Indeed, the timing of the change in IMF surveillance certainly suggests the existence of a correlation between the politicisation of the debate on financial surveillance and the outcome of IMF reform. Indeed, the crisis, which was characterized by a widespread contagion from country to country and by the transmission of shocks from the financial sector to the real economy, vividly showed the implications of an ill-devised financial supervision. What was previously a technical affair 
for financial supervisors and international technical bodies quickly became a public concern, catalyzing both governments' and public opinion's attention especially in the most advanced economies.

Although the punctuated equilibrium model brings to the surface important factors that help explain changes to the Fund's surveillance policy over time, the case under investigation presents serious empirical and theoretical anomalies. The punctuated equilibrium model cannot fully explain the rapidity with which member countries converged on the proposal to change IMF bilateral surveillance into a systemic one. Indeed, assessing domestic policies from a multilateral perspective is a complex change both technically and politically. On the one hand, adopting a systemic surveillance approach presents a number of technical and operational difficulties. In particular, systemic surveillance is an activity that requires the existence of appropriate analytical tools and organizational resources to collect and analyse financial data. In this connection, systemic surveillance also presupposes the existence of member countries' willingness to cooperate with the Fund by disclosing data related to their domestic financial systems and institutions. On the other hand, whereas under Article IV of the IMF's Articles of Agreement members are not required to change their domestic policies in circumstances where they do not undermine domestic stability, irrespective of their international effects; under the new systemic surveillance the IMF can request countries to change domestic policies because of considerations not of domestic but international well-being. In light of the complexities associated with the decision to adopt a systemic approach to surveillance, an explanation that emphasizes the role played by external shocks and governmental attention has difficulty explaining the process through which significant transformations quickly materialize.

Building on these observations, the paper argues that the latest transformation in the Fund's surveillance, entailing a quick and dramatic shift from one-country to systemic assessment of risk, did not follow a punctuated equilibrium pattern. Rather, the transformation of IMF surveillance policy is more the result of preceding events than an independent observation. Certainly, the 2007-09 financial shock with the attendant peak of public and government attention are important factors in explaining the change in the Fund's policy. However, the impact of these factors cannot be fully appreciated without putting them into the context of the decade of learning and reform that preceded the latest financial crisis.

As Hugh Heclo (I974) has powerfully argued, policy-making is not solely 'powering' but also a form of collective 'puzzlement' on society's behalf. This is particularly evident in the IMF where the process of finding solutions to economic puzzles stands at the core of the mandate of the organization. Two main collective actors are involved in the process: the staff and the Executive Board. 
The staff of the IMF is a textbook example of well-developed and autonomous international bureaucracy (Barnett and Finnemore 2004). Its members, who are primarily recruited from Anglo-American universities, include almost exclusively $\mathrm{PhD}$ economists with a macroeconomics expertise (Momani 2005b; also Chwieroth 2010). The technical and specialized background of its staff make the IMF well-placed to act as a research organization, as attested by the number of publications that the Fund regularly produces. The common educational background, combined with the hierarchical organization of IMF staff members, whose work is organized in few organizational levels within well-defined departments (Clark i996: I75), also contribute to the development of a cohesive voice on most of the issues relevant to the Fund's activity. Staff examine a variety of economic problems from inflation and consumption patterns to financial volatility, review existing literature on the topics of interest, and assess the viability of existing theoretical assumptions against historical experience. This process is often summarized in the staff memoranda (SM) that the Managing Director, the head of the staff, transmits to the Executive Board as part of the preparatory work to its meetings. Staff memoranda are particularly important to the policy-making process. Indeed, they frame the problem at stake and contain a number of policy proposals for its solution.

The Executive Board is the Fund's main decision-making body because it conducts the day-to-day operation of the Fund. It is 'in continuous session', that is, it meets as often as the business at hand requires. ${ }^{5}$ The Board discusses and decides on virtually all aspects of the Fund's activity from financial assistance programs to administrative and budgetary matters. In the area of surveillance, the Board's main responsibilities include the discussion of Article IV reports and of the principles that guide the staff's surveillance work. Although the IMF is a quasi-universal organization, with a membership of 187 countries, the Board is made up by 24 Directors. Specifically, whereas some countries have their own representative (China, France, Germany, Japan, Russia, China, Saudi Arabia, UK, US), the other members are organized in constituencies (Woods and Lombardi 2006). On top of the unequal representation, voting rights are primarily allocated by economic size (Woods 2000). As a result, the United States, in particular, and the most economically advanced countries, in general, have long enjoyed a veto power in the organization. ${ }^{6}$ Nevertheless, note should be taken that, in spite of the weighted voting system, the Executive Board decides almost exclusively by consensus, which, according to the Rule C-Io of the IMF's Bylaws, entails that 'the Chairman shall ordinarily ascertain the sense of the meeting in lieu of a formal vote' ${ }^{7}$ Of course, the consensus rule does not eliminate the effects of the weighted voting system - in order to ascertain the consensus, the Managing Director has to assess whether a decision is supported by Executive Directors having sufficient votes to carry 
the question if a vote were taken. Nevertheless, the consensus rule is conceived as an instrument that facilitates large coalition-building within the Fund's heterogeneous membership (Van Houtven 2002).

The macroeconomic background of IMF staff members and the peculiarities of the Board composition help explain the delayed effects of the learning process that followed the Mexican and the Asian financial crises. As anticipated in the Introduction, although the two crises showcased the risks of financial sector weaknesses to global stability and well-being, the staff's macroeconomic and hierarchical culture constrained the supply of new policy ideas on how to improve financial supervision. That is to say, the staff continued praising the virtues of the principles of market discipline and selfregulation (IEO 20II). This tendency was reinforced by the lack of demand on the part of the Executive Board. Being dominated by countries with lighttouch supervisory systems, the Board provided no incentive for the staff to push through radical policy ideas to reform IMF surveillance. The IMF's ability to correct its surveillance weaknesses on the basis of experience was thereby hindered by the staff's deferential attitude towards the supervisory preferences of the US, UK, and other advanced countries authorities (IEO 200I: 2I). As a result, the lessons drawn from the ig9os crises were translated only in small changes to IMF surveillance. Rather than a significant transformation of existing instruments and practices, the Fund limited its reforms to the expansion of its research activity on financial sector issues, the addition of new policy instruments to its surveillance toolkit, and the conversion of its organizational resources to the task of financial sector monitoring.

Although small and incremental, the influence of the changes adopted as a response to the I990s crises should not be underestimated. Indeed, 'choices in one period not only limit future options' but also 'structure available options' in the future (Haydu I998: 353). In other words, past solutions provide actors with the building blocks for coping with future problems and challenges - as the findings of the case under investigation suggest. Indeed, in the wake of the global financial crisis, IMF staff members built on previous transformations to sponsor the role of the Fund as a systemic supervisor and to forge a supportive coalition among member countries. Specifically, when the global financial crisis brought to the surface the weaknesses of microprudential supervision, IMF staff members drew on the availability of theoretical and organizational resources developed after the I99os crises to make their case for redressing IMF surveillance towards a systemic approach. Furthermore, these policy entrepreneurs capitalized on pre-formed political support, nurtured in previous rounds of reforms, to push quickly the issue of systemic surveillance into the decision-makers' political agenda. In what follows, I am thereby going to provide the empirical evidence related to the impact of lagged learning on the $2009^{-}$Io reform to IMF surveillance. 


\section{The IMF and Bilateral Surveillance: From a One-country Focus to a Systemic Approach}

As the IMF website explains, when a country joins the IMF, it agrees to subject its economic and financial policies to the scrutiny of the organization. 'The IMF's regular monitoring of economies and associated provision of policy advice is intended to identify weaknesses that are causing or could lead to financial or economic instability. This process is known as surveillance. ${ }^{8}$ In IMF terminology, it is customary to distinguish between bilateral and multilateral surveillance to indicate the two broad categories of IMF surveillance activity (see, for instance, IEO 2006). Whereas bilateral surveillance refers to the IMF's oversight activity over the policies of individual countries, multilateral surveillance refers to the analysis of global economic and market developments conducted in the Fund's flagship publications - i.e. the World Economic Outlook (WEO) and the Global Financial Stability Report (GFSR). For the purposes of this paper, in the next sections, surveillance refers to the bilateral type although, as explained at greater length below, one of the implications of the recent change to the Fund's surveillance is that of blurring the line between bilateral and multilateral surveillance.

As far as concerns bilateral surveillance, the Fund discharges this activity through periodic consultations with all member countries as requested by Article IV of its Articles of Agreement. Bilateral surveillance is a regular activity: it usually takes place on an annual basis when a team of IMF economists visits a country to assess economic and financial developments and discuss the country's economic and financial policies with national authorities. Bilateral surveillance is also mandatory: members are required to consult with the Fund when requested, and to provide the Fund with the information it may require for this purpose. Furthermore, members assume an obligation to adjust their policies in circumstances where they undermine the member's own domestic stability. That is to say, surveillance primarily has a one-country focus, assessing the implications of each country's policies for its economic and financial stability. Accordingly, 'spillovers from members' domestic policies in these circumstances cannot be the primary subject of bilateral surveillance' (IMF 20I0: 2).

Although today's surveillance covers virtually all aspects of member countries' economic and financial choices, the original core of the Fund surveillance is macroeconomics. That is to say, the IMF has traditionally analysed and provided advice on issues such as the choice of the exchange rate and the consistency between the regime of fiscal and monetary policy. In contrast, financial sector issues were not properly incorporated in surveillance reports in a reflection of the conditions that existed at the time of the Fund's creation in 1944, when the international economic system was organized around the pillars of fixed exchange rates and liberal trade but 
also of controls on capital flows. The macroeconomic core of IMF surveillance also reflects the composition of its staff, whose members are largely recruited from the macroeconomics profession (Momani 2005a).

Starting in the early I99os, however, the scope of IMF surveillance has been significantly expanded so as to include financial sector issues. That is to say, member countries' policies meant to regulate financial market actors and products, were inserted in the analyses conducted by IMF staff members. Several factors contributed to the changes in IMF surveillance including the growing integration of global financial markets and the attendant recognition of the risks that such integration entails as exemplified in the financial crises of the ig9os. In particular, the crises provided the experience for the IMF to learn about the implications of macro-financiallinkages, that is, the two-way relationship between the conditions of the financial sector and macroeconomic stability.

The 2007-og financial crisis has once again sparked an intense debate on the reform of IMF surveillance to minimize the likelihood of future crises (IMF 200gb). These considerations culminated in a number of significant changes to the Fund's surveillance approach. For instance, in the immediate aftermath of Lehman Brothers collapse, member countries sitting in the IMF Board issued the Statement on Surveillance Priorities (SSP) that provides operational guidance to IMF staff on the conduct of bilateral surveillance (IMF 2008b). Specifically, the SSP, which were released in October 2008, put the emphasis on external stability as a guiding principle of IMF surveillance. For instance, IMF staff has been mandated to improve analysis of financial stability, and deepen the understanding of the real-financial markets linkage. Furthermore, and most important to the purpose this study, in October 2009, member countries mandated that Fund surveillance has to analyze the outward spillovers of domestic financial policies (IMF 2009a). In this connection, IMF staff members are also discussing the political feasibility of adopting a Multilateral Surveillance Decision to clarify the scope and modalities of systematic surveillance. IMF staff members are also proposing to test a new type of surveillance reports - i.e. spill-over reports - for a number of systematically-important countries, including the United States, China, Japan, the Euro Area and the $\mathrm{UK}$ (IMF 20I0). In what follows, I attempt to gauge how much of this rapid and radical shift towards systemic supervision can be attributed to the cumulative effects of previous policy choices.

\section{Explaining the Shift to Systemic Supervision}

\section{I. The first steps: Learning from the I9gos crises}

Although the Fund carries out the surveillance task since the time of its creation, its systematic involvement in financial sector surveillance is relatively 
new because it can be traced back to the 1994 Mexican and 1997-98 Asian financial crises (Gola and Spadafora 2009: 3). Both crises offered a conspicuous example of the implications of weak financial systems and of the speed with which financial vulnerabilities spread across the globe. ${ }^{9}$ In the Mexican case, although the crisis started as a typical macroeconomic crisis, triggered by growing budget deficits and rising inflation, the crisis intensified because of the fragility of the domestic banking sector and because investors reacted by withdrawing from emerging markets funds. That is to say, the events in Mexico in December 1994 prompted a broad sell-off of developing countries securities. If Mexico had rung an alarm bell on the destabilizing effects of shifts in market sentiment, Asia was a dramatic confirmation-test. Countries that right up to the crisis had received the largest share of capital inflows among developing countries experienced capital reversals of unprecedented scale. Financial sector weakness played a key role in the crisis. In particular, substantial foreign borrowing by the private sector and a weak and over-exposed banking system significantly contributed to the severity of the Asian crisis and its contagion. ${ }^{\mathrm{IO}}$

The experience of the crises sparked an intense in-house reflection within the IMF - also because the Fund's failure to identify the risks coming from the domestic financial sector in both the Mexican and the Asian crisis laid bare the need to reform its surveillance (Moschella 2010: 8 ${ }^{-} 4, \mathrm{I}_{2} 5^{-6}$ ). Three main lessons were drawn from the experience of the crises, as evidenced in the findings of the main reports that assessed the performance of the Fund's surveillance activity (IMF I997, I998, I999). To start with, it became clear that the Fund needed to develop its knowledge on financial sector issues and their interaction with the real economy. For instance, in the aftermath of the Mexican and the Asian crises, the internal reviews on IMF surveillance emphasised that Fund staff had not sufficiently focused on financial sector developments, including developments in the banking and financial sector (IMF 1997: 20). Secondly, an important lesson from the crises was that the Fund needed new instruments to conduct surveillance. Indeed, the shortcomings in the oversight activity of the Fund were attributed to the fact that Fund surveillance had been traditionally mostly concerned about macroeconomic policy mix, with the result that 'Fund missions were sometimes not fully aware of the scale of ... financial sector problems' (IMF I998: 3). Finally, the crisis revealed the weaknesses in IMF staff's organizational and analytical skills. That is to say, IMF staff members were regarded as not having appropriate financial training, being overwhelmingly recruited from the macroeconomics profession.

Building on these lessons, the IMF started a process of reform of its surveillance. Interestingly, however, the lessons drawn from the crises did not bring about radical transformations primarily because the staff's macroeconomic culture significantly hindered the embrace of financial 
sector surveillance (Moschella 2012). Combined with the general satisfaction with existing microprudential surveillance in most advanced economies, ${ }^{\text {II }}$ the I99os reform process was thereby characterized by a small and incremental pattern of change: new knowledge and instruments were added to the existing surveillance toolkit and human resources were redirected to new goals.

To start with, as a response to the crises of the r99os, the Fund started developing knowledge on financial sector issues and their implications for domestic and international stability. ${ }^{12}$ This has been done in two steps. First, IMF research showed that the potential connection between financial sector policies and financial crises identifying the major sources of risks

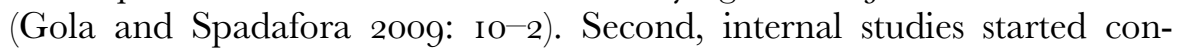
necting financial sector surveillance with a systemic focus. As one of the internal reviews prepared by IMF staff put it, 'systemically important countries include 'both countries whose capital markets intermediate the bulk of global financial transactions, and emerging countries whose financial system have the potential to cause, or be subject to, undue volatility in cross-border flows and financial system contagion' (IMF 2000: 29).

Next to the development of the analytical framework on what systemic surveillance entails, the lessons drawn from the iggos crises also contributed to the development of a new set of instruments relevant to the systemic surveillance exercise. Specifically, two new instruments were created for the analysis of domestic and global financial systems - i.e. the Financial Sector Assessment Program (FSAP) and the Global Financial Stability Report (GFSR). The FSAP was launched in May I999 as an add-on to the Article IV surveillance reports; the Program was conceived as an instrument through which to identify financial sector vulnerabilities across IMF membership. In particular, similarly to Article IV reports, the reports prepared under the framework of the FSAP aim at monitoring the soundness of members' policies. In contrast to Article IV reports, however, the focus of the FSAP is solely on the financial system. The GFSR, in turn, was launched in March 2002 in order to improve the Fund's capacity to understand the dynamics of global financial markets. Specifically, the GFSR is a biannual publication that complements the Fund's flagship publication - i.e. the World Economic Outlook - by focusing on 'current market conditions, highlighting systemic issues that could pose a risk to financial stability'. ${ }^{3}$

Over the r9gos, important changes were also implemented in the organizational structure of the IMF. In particular, a number of reforms contributed to converting IMF staff expertise towards financial surveillance. For instance, in April 2002 the Board approved a measure according to which Article IV mission teams, whose members usually come from area departments, ${ }^{14}$ would have been reinforced by deploying staff coming from financial sector departments such as the Monetary and Exchange Affairs Department (MFD) or the International Capital Market Department (ICMD) 
(Gola and Spadafora 2009: 50-I). The ICMD, in turn, was itself created in 200 i to strengthen 'the Fund's conceptual work related to the international financial system and to capital market'. ${ }^{15}$

Along with the analytical framework, the instruments, and the organizational resources needed to carry out financial surveillance with a systemic perspective, the policy changes adopted before the burst of the 2007-09 crisis also helped shape the political support around the reorientation of the Fund surveillance towards a systemic approach. The Decision on bilateral surveillance adopted by the Executive Board in June 2007 is illustrative in this regard. Indeed, as already anticipated, under Article IV, members are not required to change their domestic policies in circumstances where, despite the fact that these policies may have negative externalities, they do not undermine the member's own domestic stability. In contrast, the 2007 Decision introduced the standard of 'external stability' to assess members' domestic policies (IMF 2007). In other words, although the 2007 Decision was primarily directed at assessing the external consequences of domestic exchange rate policies, its adoption suggests that, well before the global financial crisis burst, member countries have already converged around the view that member countries' policies should be assessed not only from the perspective of one-country stability but also of systemic stability.

\subsection{Lagged learning and the global financial crisis}

The changes to IMF surveillance analyzed thus far significantly shaped the Fund's response to the global financial crisis that started in 2007. Indeed, previously adopted changes provided the building blocks upon which the shift to a systemic approach to IMF surveillance materialized. Specifically, IMF staff members used the effects of previous policy changes to advance their proposal on systemic supervision and to forge member countries' consensus around such a proposal. The documents prepared as background material to the IMF Board's discussion well illustrate this point. Indeed, in most of the documents that served as a basis for the Board's decisions, IMF staff members pointed at the existence of available knowledge, instruments, expertise, and political support in order to introduce the systemic approach to the Fund's financial supervision. In this connection, IMF staff motivated the adoption of a systemic approach by referring to the analytical and organizational resources available to the Fund through instruments such as the FSAP and Global Financial Stability Report. Furthermore, in order to advance their proposal, IMF staff also explicitly linked the shift to systemic surveillance with the 2007 Decision, thereby catalyzing on existing political support.

For instance, in the background paper to the Board's 2008 review of surveillance (IMF 2008a), IMF staff members suggested a number of policy 
recommendations through which to enhance the systemic focus of IMF surveillance, and which formed the basis of the already mentioned Statement on Surveillance Priorities (SSP) adopted by the Board in the fall of 2008. Among others, IMF staff suggested 'developing a framework for more systematic macro-financial surveillance ...; further building financial expertise ...; and continuing to develop methodologies and toolkits' (IMF 2008a: 4, emphasis is mine). Interestingly, as the language emphasized in the quotation reveals, IMF staff considered the recommended actions as being already part of the Fund's policy toolkit. That is to say, the Fund had not to develop a framework for systemic surveillance or create expertise and resources from scratch, but have to continue improving and expanding on existing frameworks, expertise, and resources. Commenting their recommended policy actions, IMF staff therefore concluded that in order to reform IMF surveillance, including by giving it a systemic focus, "may simply require better aligning processes and resources and "just doing it," because the expertise, the tools and, the data are already there' (IMF 2008a: II). In this connection, the staff called on to improve the already available FSAP by integrating its findings with those conducted within the framework of the traditional IMF macroeconomic surveillance (IMF 2009c). Furthermore, progress on shifting IMF surveillance towards a systemic approach could be achieved through better leveraging the analytical findings of existing analyses, in particular, the analysis of the global financial system conducted in the Global Financial Stability Report. In short, IMF staff members identified a number of 'good practices', already available within the Fund as the result of previous rounds of reform, needing to be mainstreamed into the Fund's systemic surveillance.

Preparing the background documents to the IMF Board's discussion, IMF staff also extensively referred to the political support to IMF's surveillance as developed from the reform embodied in the 2007 Decision. Indeed, the 2008 Triennial Surveillance Review repeatedly emphasizes how, as a result of previous changes to IMF surveillance, including the changes introduced by the 2007 Decision, today's IMF surveillance is held in high regard both among its members and other stakeholders, such as market participants. To capitalize on the results achieved thus far, IMF staff therefore suggested shifting to a systemic approach by proceeding along the path set by the 2007 Decision. That is to say, the shift in the approach to financial sector surveillance should take place by clearly encompassing 'assessments of external stability risks' in the surveillance of domestic policies and the exchange rate policy in particular (IMF 2008a).

Having shown that the Fund possesses the instruments and the resources for conducting systemic surveillance, IMF staff facilitated agreement among member countries. Indeed, the IMF Board quickly adopted the surveillance priorities suggested by IMF staff in the Triennial Surveillance Review and 
endorsed most of the recommended initiatives, including the launch of systemic surveillance reports (IMF 2009b). Indeed, as the summary of the discussion held within the Board reveals, most Directors regarded the staff's proposals to reform IMF surveillance as being in line with the conceptual and operational capacity available within the Fund. In this connection, Directors agreed that giving financial sector surveillance a systemic focus requires further developing existing capacity for financial sector analysis and improving existing instruments such as the Financial Sector Assessment Programs (FSAPs). ${ }^{16}$ In other words, Directors agreed on expanding on the results of previous reforms. Furthermore, members' preferences for reforming IMF surveillance were also shaped by the evolution of IMF surveillance that led to the 2007 Decision. Indeed, it would be difficult in 2008 to imagine members' support for proceeding 'expeditiously' on issues related to the shift to external stability as the standard to assess domestic policies, if the 2007 Decision had not helped accept the principle that effective IMF surveillance requires assessing domestic policies also in light of their international implications. ${ }^{17}$

In short, the strategic use of the effect of past policy solutions by IMF staff allowed for the quick and profound transformation of IMF surveillance in 2008-09. Past policies structured the options available to the Fund because they revealed that the Fund possessed the in-house knowledge, expertise, instruments, and support for moving to a new type of surveillance. Absent these conditions, a complex change such as the one toward systemic supervision could not have happened so rapidly as it did. In particular, none of the demanding technical and political pre-conditions for the conduct of systemic supervision could have been rapidly put in place in the short-time span that separated the burst of the crisis and the reform of the Fund surveillance. Rather, these conditions were already available, being the result of the slow and incremental changes adopted since the mid-rg9os.

\section{Conclusions}

The shift to a systemic approach to financial regulation and supervision is one of the major developments in response to the 2007-09 financial crisis. Indeed, domestic and international regulators are converging around the view that an effective governance of the financial system requires adopting a macroprudential or systemic outlook, one that takes into account the safety and soundness of the financial system as a whole, as well as individual institutions. In this connection, market discipline and self-regulation are no longer regarded as the only viable mechanism with which to ensure financial stability (Bernanke 2009, IMF, Bank for International Settlements, and the Financial Stability Board 2009). This paper has explored such an emerging change in the approach to global financial governance through 
the prism of the change in IMF surveillance. That is to say, the paper has asked about the factors that help account for the deep and profound transformation that led the Fund to take a systemic approach in the conduct of its bilateral surveillance. Indeed, member countries quickly reacted to the crisis by shifting IMF bilateral surveillance from a one-country to a multilateral or systemic approach. That is to say, the IMF has been asked to assess member countries' domestic policies not only in light of their implications for the domestic economy but also in light of their spill-over effects on other countries.

Analysing the pattern of transformation in the Fund's policy, the paper has argued that, while the crisis was certainly an important catalyst, the causes that explain the rapid and substantive shift in the scope of IMF surveillance lie in the cumulative effects of the lessons drawn from the ig9os financial crises and the attendant policy changes. Specifically, the paper has illustrated that the Mexican and the Asian crises had already raised the need to reform IMF surveillance by showcasing the risks of financial sector weaknesses to global financial stability. Nevertheless, the lessons drawn from the two crises did not lead to a radical transformation of IMF surveillance. Rather, the macroeconomic expertise of IMF staff and the microprudential preferences of the advanced countries well-represented in the Executive Board combined to produce a process of lagged learning that materialized in a pattern of small and incremental change to IMF surveillance. As a result, new knowledge and instruments were added to the existing surveillance toolkit and human resources were redirected to new goals.

Although small and incremental, the implications of the lessons from the I99os crises should not be underestimated. Indeed, the findings of the paper indicate that the gradual changes enacted after the Mexican and Asian experience proved crucial to the transformation of the Fund surveillance in the aftermath of the 2007-09 crisis. In particular, IMF staff members capitalised on the effect of previous policy choices in order to introduce the systemic approach to IMF surveillance. Acting as policy entrepreneurs, the staff utilized the theoretical and organizational resources developed from past incremental changes to make the case for the Fund's ability to act as a systemic supervisor and to win member countries' approval.

Having shown that the cumulative effect of previous policy changes created the conditions for a quick and radical transformation of IMF surveillance, the paper stresses the importance of temporality and process sequencing to explain both gradual and abrupt policy change (Haydu I998; Howlett 2009). Unlike most path-dependent analyses, this paper found evidence that there the $2007^{-}$- 9 crisis cannot be considered as a random turning point that sets in motion the process of change. Rather, the crisis interacted with the effects of previous policy changes. The impact of the crisis on the IMF policy was therefore filtered through the outcome of past 
policy choices. In this connection, policy change appears as firmly rooted in previous trajectories with the result that, 'gradually unfolding changes may be hugely consequential as causes of other outcomes' (Mahoney and Thelen 20I0: I).

The paper has also attempted to expand the research agenda of policy studies by analyzing a policy of an international organization. Although this attempt may feed into the problem of the dependent variable, by adding to the complexity of the explanandum (i.e. policy change) (Capano 20o9; Howlett and Cashore 2009), the reasons to leave the activities of IOs outside the purview of policy studies are not substantive. Indeed, most international organizations take actions to solve societal problems similarly to what is expected from public policies. In terms of the policy-making process, then, like any public policy, the policies adopted by several IOs take place in the presence of multiple constraints, including time and resource constraints during financial crises for instance. The different stages of the policy-making process of most IOs are also defined $e x$ ante in their constitutional charters and involve a variety of actors with the task of drafting, adopting and implementing policies. Of course, IOs differ in terms of the characteristics of the policy-making systems; but this opens up the possibility for comparative analyses, thereby making IOs an appealing field to policy scholars.

\section{NOTES}

I. For instance, this is the purpose of the 2003 Basel II banking accord. Specifically, Basel II capital requirements are meant to contain the risks each bank faces in the domestic financial system as a result of its lending and trading practices.

2. For an analysis of the factors that make changes to IMF's policies slow and difficult to be adopted see, for instance, Vetterlein (2006).

3. As the IEO (200I, 6 emphasis is mine) summarizes it, in the run-up to the crisis, 'the IMF appropriately stressed the urgency of addressing the persistent and growing current account imbalances, but it did not look at how these imbalances were linked to the systemic risks that were building up in financial systems.'

4. The characteristics and the actors involved in Fund's policy-making process are detailed below.

5. The Board exercises all the powers for conducting the IMF's business except those that the Articles of Agreement have reserved for the Board of Governors, which is the supreme organ of the IMF. The Board of Governors consists of one representative for each member country and, in contrast to the Executive Bard, meets normally twice a year. For a thorough analysis of IMF governance see Van Houtven 2002.

6. To remedy this problem, the IMF has recently embarked on a extensive reform of its governance. IMF website http://www.imf.org/external/np/sec/misc/consents.htm\#ar.

7. The Chairman is usually the Managing Director or his/her Deputy.

8. IMF website, Surveillance, http://www.imf.org/external/about/econsurv.htm (accessed I7 March 2009).

9. The literature on the Asian crisis is extensive and references are simply indicative here. For detailed analyses of the Asian crisis from an economics perspective: Krugman I995; and Goldstein I998. For accounts of the crisis from a political economy perspective: Haggard 200o; Noble and Ravenhill 2000; Moschella 20Io.

Io. On the implications of the financial sector weaknesses for the reform of the international financial architecture see, for instance, Walter (2008).

II. For instance, in the aftermath of the Asian crisis, developed countries supported the international financial standard initiative to improve global financial surveillance (Drezner 2007; Walter 2008). The initiative was staked on the assumption that financial stability would be preserved to the extent that emerging and developing countries would have embraced the financial supervisory and regulatory 
frameworks of the most advanced financial centers - which, ironically, were exactly the countries were the global financial crisis burst in 2007.

I2. However, the most important advances in the development of a systemic approach to financial regulation and supervision have been done within the Bank for International Settlements. See, for instance, Borio et al. 200I; and Borio and White 2004.

I3. IMF website, About the Global Financial Stability Report, Available at http://www.imf.org/ external/pubs/ft/gfsr/about.htm (accessed 26 March 20Io).

I4. Area departments are responsible, across macro-geographical regions, for Article IV consultations. In contrast functional departments are those most involved in the Fund's research work including, for instance, the Research Department.

I5. IMF, Establishing International Capital Markets Department, News Brief N ${ }^{\circ}$ ог/24, I March 200I. In 2006, ICM was merged with MFD creating the Monetary and Capital Markets Department.

I6. IMF, IMF Executive Board Reviews the Fund's Surveillance, Public Information Notice (PIN) No. 08/I33 II October 2008. Available at http://www.imf.org/external/np/sec/pn/2008/ pno8I33.htm (accessed 23 September 20I0).

17. Ibid.

\section{REFERENCES}

Baker A. (2010) Financial Booms, Crisis Politics and Macroprudential Regulation: The Political Economy of an Ideational shift. Paper presented at the AGORA workshop on Global Knowledge Networks, Brown University, $2 \mathrm{I}^{-2}$ June.

Barnett M. N. and Finnemore M. (2004) Rules for the World: International Organizations in Global Politics. Ithaca, New York: Cornell University Press.

Baumgartner F. R. and Jones B. D. (1993) Agendas and Instability in American Politics. Chicago: University of Chicago Press.

Bernanke B. (2009) Testimony before the Committee on Financial Services, U.S. House of Representatives, Washington, D.C., 24 July.

Borio C. and White W. (2004) Whiter Monetary and Financial Stability: The Implications for Evolving Policy Regimes. BIS Working Papers I47, Bank for International Settlements, Basel.

Borio C. et al. (200I) Procyclicality of the Financial System and Financial Stability Issues and Policy Options. BIS Papers I(March): $\mathrm{I}^{-} 57$.

Capano G. (2009) Understanding Policy Change as an Epistemological and Theoretical Problem. Fournal of Comparative Policy Analysis: Research and Practice II(I): 7-31.

Cashore B. and Howlett M. (2007) Punctuating Which Equilibrium? Understanding Thermostatic Policy Dynamics in Pacific Northwest Forestry. American Fournal of Political Science 5I(3): 532-55I.

Chwieroth J. M. (2010) Capital Ideas: The IMF and the Rise of Financial Liberalization. Princenton: Princenton University Press.

Clark I. (I996) 'Inside the IMF: Comparisons with Policy-making Organizations in Canadian Governments'. Canadian Public Administration 39(2): I57-I9I.

Drezner D. W. (2007) All politics is global: Explaining international regulatory regimes. Princeton: Princeton University Press.

Gola C. and Spadafora F. (2009) Financial Sector Surveillance and the IMF. IMF Working Papers $\mathrm{WP} / \mathrm{og} / 247$.

Goldstein M. (1998) The Asian Financial Crisis: Causes, Cures, and Systemic Implications. Washington, D.C.: Institute of International Economics.

Hall P. A. (I993) Policy Paradigms, Social Learning, and the State: The Case of Economic Policymaking in Britain. Comparative Politics 25(3): 275-296.

Haydu J. (1998) Making Use of the Past: Time Periods as Cases to Compare and As Sequences of Problem Solving. American fournal of Sociology I04(2): 339-371.

Heclo H. (1974) Modern Social Politics in Britain and Sweden. New Haven: Yale University Press.

Helleiner E. et al. (eds.) (2009) Global Finance in Crisis. The Politics of International Regulatory Change. London: Routledge.

Howlett M. (2009) Process Sequencing Policy Dynamics: Beyond Homeostasis and Path Dependency. Fournal of Public Policy 29(3): $24 \mathrm{I}^{-}-262$.

Howlett M. and Cashore B. (2009) The Dependent Variable Problem in the Study of Policy Change: Understanding Policy Change as a Methodological Problem. Fournal of Comparative Policy Analysis: Research and Practice II(I): $33^{-}{ }^{6}$. 
Independent Evaluation Office (IEO) (201 I) IMF Performance In the Run-Up to the Financial and Economic Crisis: $I M F$ Surveillance in 2004-2007. Washington, D.C.: International Monetary Fund.

Independent Evaluation Office (IEO) (2006) Multilateral Surveillance. Washington, D.C.: International Monetary Fund.

IMF (I997) Biennial Review of the Implementation of the Fund's Surveillance over Members' Exchange Rate Policies, and of the 1977 Surveillance Decision. IMF Archives, SM/97/53 (Washington: International Monetary Fund, I9 February 1997).

IMF (I998) Review of Members' Policies in the Context of Surveillance Lessons for Surveillance from the Asian Crisis. IMF Archives, EBS/98/44 (Washington: International Monetary Fund, 9 March 1998).

IMF (I999) External Evaluation of IMF Surveillance. Report by a Group of Independent Expert. IMF Archives, EBAP/99/86 (Washington, D.C.: International Monetary Fund, I5 June 1999).

IMF (2000) Financial Sector Assessment Program: A Review-Lessons from the Pilot and Issues Going Forward. IMF Archives, Washington, D.C., SM/oo/263. 27 November 2000.

IMF (2007) Bilateral Surveillance over Members' Policies. Executive Board Decision, I5 June 2007.

IMF (2008a) 2008 Triennial Surveillance Review-Overview Paper. Washington, D.C.: International Monetary Fund, 2 September.

IMF (2008b) IMF Executive Board Adopts Surveillance Priorities for 2008-20II. Press Release No. 08/238. 8 October.

IMF (2009a) Bilateral Surveillance Guidance Note. Washington D.C.: International Monetary Fund, 27 October.

IMF (2009b) Communique of the International Monetary and Financial Committee of the Board of Governors of the International Monetary Fund, 25 April.

IMF (2009c) Financial Sector and Bilateral Surveillance-Toward Further Integration. Washington, D.C.: International Monetary Fund, 28 August.

IMF (2010) Review of the Fund's Mandate-Follow-Up on Modernizing Surveillance, Washington, D.C.: International Monetary Fund, 3o July.

IMF, Bank for International Settlements, and the Financial Stability Board (2009) Guidance to Assess the Systemic Importance of Financial Institutions, Markets and Instruments: Initial Considerations, October.

Kodres L. and Narain A. (2010) Redesigning the Contours of the Future Financial System, IMF Staff Position Note Washington D.C.: International Monetary Fund.

Krugman P. (I995) 'Dutch Tulips and Emerging Markets'. Foreign Affairs 74(4): 28-44.

Mahoney J. and Thelen K. (2010) A Theory of Gradual Institutional Change. In Mahoney J. and Thelen K. (eds.), Explaining Institutional Change. Ambiguity, Agency, and Power. Cambridge: Cambridge University Press.

Martin L. L. and Simmons B. A. (I998) Theories and Empirical Studies of International Institutions. International Organization 52(4): 729-757.

Momani B. (2005a) Limits on Streamlining Fund Conditionality: The International Monetary Fund's Organizational Culture. Fournal of International Relations and Development 8(2): ${ }_{4} 42^{-}{ }^{-1} 63$.

Momani B. (2005b) Recruiting and Diversifying IMF Technocrats. Global Society I9(2): I67-I87.

Moschella M. (2012) IMF Surveillance in Crisis. The Past, Present, and Future of the Reform Process. Global Society 26(I).

Moschella M. (2010) Governing Risk: The IMF and Global Financial Crises. Basingstoke: Palgrave Macmillan.

Newton K. and van Deth J. W. (2005) Foundations of Comparative Politics. Cambridge: Cambridge University Press.

Noble G. W. and Ravenhill J. (eds.) (2000) The Asian Financial Crisis and the Architecture of Global Finance. Cambridge: Cambridge University Press.

Seabrooke L. (2007) Legitimacy Gaps in the World Economy: Explaining the Sources of the IMF's Legitimacy Crisis. International Politics $44^{(2-3)}: 25^{-2} 268$.

Strauss-Kahn D. (2010) Crisis and Beyond - the Next Phase of IMF Reform, Speech delivered at the Peterson Institute for International Economics Washington D.C., 29 June.

Streeck W. and Thelen K. (eds.) (2005) Beyond Continuity: Institutional Change in Advanced Political Economies. Oxford: Oxford University Press.

Thelen K. (2004) How Institutions Evolve. The Political Economy of Skills in Germany, Britain, the United States, and Japan. Cambridge: Cambridge University Press.

True J. L. et al. (I999) Punctuated-equilibrium Theory: Explaining Stability and Change in American Policy making. In Sabatier P. (ed.), Theories of the policy process. Oxford: Westview Press.

Van Houtven L. (2002) Governance of the IMF. Decision making, Institutional Oversight, Transparency and Accountability. Washington, D.C.

Walter A. (2008) Governing Finance: East Asia's Adoption of International Standards. Ithaca: Cornell University Press. 
Woods N. (2000) The Challenge of Good Governance for the IMF and the World Bank Themselves. World Development 28(5): 823-84I.

Woods N. and Lombardi D. (2006) Uneven patterns of governance: how developing countries are represented in the IMF. Review of International Political Economy I3(3): 480-515.

MANUELA MOSCHELLA

Department of Sociology and Social Research

University of Trento, Italy

Via Verdi 26, 38 Ioo Trento

Tel: +39 o46I 881386; Fax: + 39 o46I 881348

e-mail: Manuela.Moschella@sis.unitn.it 